\title{
欧米の臨床試験でフィブリノゲン製剤が 有効性に乏しい理由に関する考察
}

木倉晆人*

[要旨] 欧米の無作為比較試験において人工心肺離脱期のフィブリノゲン值は平均 170 180mg/dLとトリガー值としてかなり高い. また，200〜250mg/dLを目標として濃縮フィ ブリノゲン3〜 6g を投与しても止血と輸血節減の効果に乏しかった. その理由には, 新鮮凍結血 漿で対応可能な症例が多く，フィブリノゲン製剤の有効性が十分に実証されなかったことがあげら れる. 濃縮フィブリノゲンが有効な症例のトリガ一值は $130 \mathrm{mg} / \mathrm{dL}$ 未満とより低く, 有効投与量 は 2 3g 程度であろう. 今後は, 新たな観察調査や臨床試験において濃縮フィブリノゲンのトリ ガ一值と有効投与量の再設定が必要と考えられる.

キーワード：無作為比較試験, フィブリノゲン, トリガ一值, 有効投与量, 心臟血管手術

\section{緒言}

ハイリスクの心臓血管手術を対象とした最近の欧 米の無作為比較試験 ${ }^{1)}$, $)$ においてフィブリノゲン製 剤の有効性を示す有意な結果は得られなかった。本 稿ではその主な理由であるトリガー值と有効投与量 の設定について筆者らの報告と対比しながら考察す る. また, 血液凝固系の臨床研究での統計処理の工 夫や今後の臨床試験や調査をどうすべきかについて も述べる.

最近の Rahe-Meyer ら ${ }^{1)}$ (多施設, 多国間), Bilecen $ら^{2)}$ (単施設)による報告はハイリスクの心臓血管手 術を対象とした二重盲検法の無作為比較試験であ る。彼らは出血量と輸血量を主とした転帰について フィブリノゲン製剤の有効性を示すことができなか つた。厳密でかなり水準の高い臨床研究であるにも かかわらず，なぜ有効性が実証されなかったのだろ
うか. これらの報告では，投与前のフィブリノゲン 值(平均)はフィブリノゲン製剤群: $170 \sim 186 \mathrm{mg}$ /

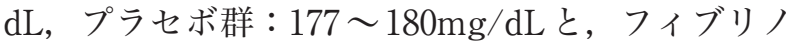
ゲン製剤を投与するトリガー值としてかなり高い症 例が対象である。

筆者らは胸部大血管手術を対象に後方視的コホー 卜研究を行い報告した ${ }^{3)}$. 人工心肺離脱期のフィブ リノゲン值が $130 \mathrm{mg} / \mathrm{dL}$ 未満のとき，濃縮つィブリ ノゲン(クリオプレシピテート，フィブリノゲン製 剂) $2 \sim 3 g$ は術後 24 時間の出血量を有意に減らし た。図1のように，筆者らの結果に欧米の臨床試験 における人工心肺離脱期のフィブリノゲン值(横軸) と術後 24 時間の出血量(縦軸)の領域(点線の範囲) を重放合わせてみる ${ }^{1) \sim 31}$. 欧米の臨床試験は濃縮フ イブリノゲンの効果がそしい領域を対象としてお り，トリガー值の設定に原因があったと考えられる. また，富田らは胸部大動脈手術におけるクリオプレ 


\section{人工心肺離脱期のフィブリノゲン值 $(\mathrm{mg} / \mathrm{dL})$ により層別化（文献 3)

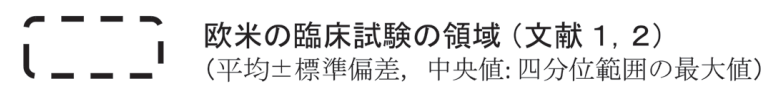

○, 実線: 濃縮フィブリノゲン投与群 $\quad \times$, 点線: 非投与群

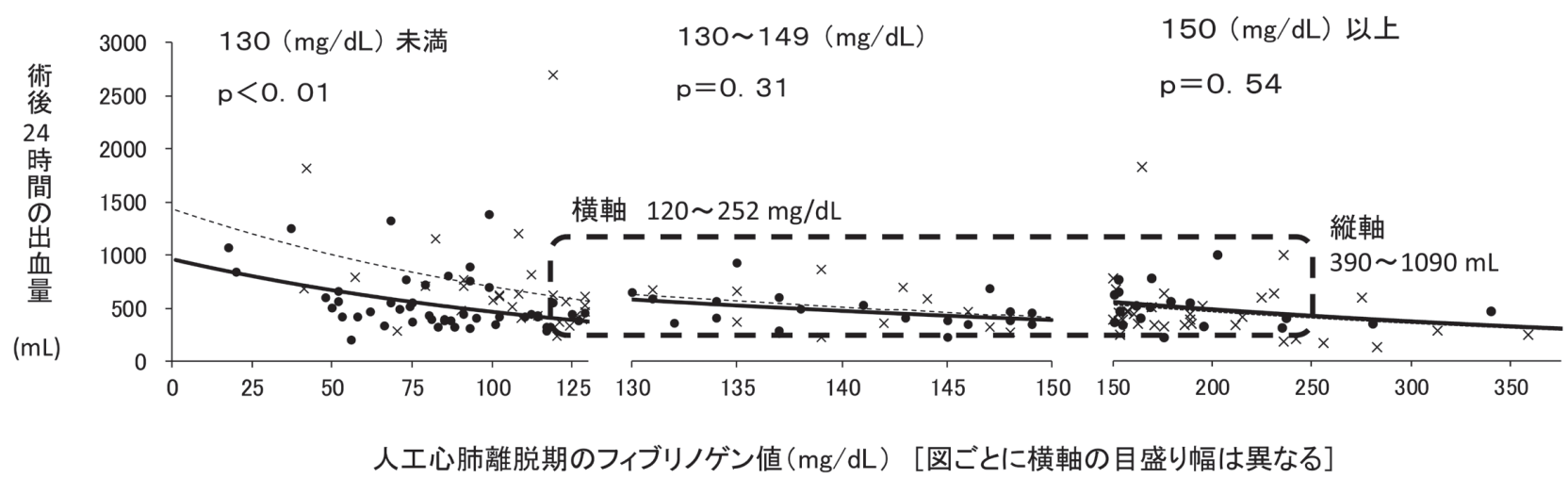

図 1 術後出血量に対する濃縮フィブリノゲンの有効性

欧米の臨床試験 ${ }^{11.22}$ のフィブリノゲン值(横軸) と術後 24 時間の出血量 (縦軸)の領域(点線範囲) を筆者らの結果 ${ }^{3)}$ に重㸚る と，欧米の試験は濃縮フィブリノゲンの効果がそしい領域を対象としている.

〔文献1) 3) 上り引用・改変〕

シピテートの止血効率を改善する有用性を報告して いる ${ }^{4)}$ そその報告では人工心肺離脱後のフィブリノ ゲン值は平均 $109 \sim 136 \mathrm{mg} / \mathrm{dL}$ であり, 筆者らの報 告における平均 $118 \sim 151 \mathrm{mg} / \mathrm{dL}$ と類似している. また，平成 29 年 3 月に改定された厚生労働省の血 液製剂の使用指針においても，新鮮凍結血漿(fresh frozen plasma : FFP)の輸血に関しフィブリノゲン のトリガー值として $150 \mathrm{mg} / \mathrm{dL}$ 未満が参考值として 示されている5).

\section{Iトリガ一值の設定について}

従来のフィブリノゲン $100 \mathrm{mg} / \mathrm{dL}$ というトリガー 值は周術期の危機的出血や外傷の止血には低すぎ る。一方，より高いトリガー值をという最近の流れ がいつのまにか $200 〜 250 \mathrm{mg} / \mathrm{dL}$ という高い目標值 の設定になっている ${ }^{6)}$. 今まで, 赤血球濃厚液はへ モグロビン $(7 \sim 9 \mathrm{~g} / \mathrm{dL})$, 血小板濃厚液は血小板数 (5〜 万万 $/ \mu \mathrm{L})$ をトリガーとして投与されている. 目標值を設定すると過剩輸血になる可能性が高く, 血液凝固因子であるフィブリノゲンも同様に目標 值よりも適切なトリガー值を設定すべきと考えら
れる。

欧米の臨床試験ではフィブリノゲンの投与量をフ イブリノゲン值やフィブリン重合の高い目標值から 計算しており，投与後に目標値には達している。し かし，濃縮フィブリノゲンが出血量や輸血量を減ら す効果は，目標值よりも前述のようにフィブリノゲ ン $130 \mathrm{mg} / \mathrm{dL}$ というトリガー值に依存する.つまり， 濃縮フィブリノゲンの効果が得られるより低いトリ ガー值を設定する必要があったと考えられる。

また, 欧米の臨床試験ではフィブリノゲン製剂(ま たはプラセボ)の適用を決めるときに人工心肺離脱 後の 5 分間の出血量をトリガーとしている.しかし, 5 分間の出血量は濃縮フィブリノゲンの効果がある 症例層を区別するための適切なトリガーとは結果的 に言い難いであろう。

\section{II 有効投与量の設定について}

欧米の臨床試験ではトリガー值よりも200〜 $250 \mathrm{mg} / \mathrm{dL}$ という高い目標值が重視された。そして 目標值に達するための $3 \sim 6 \mathrm{~g}$ という高用量のフィ ブリノゲンが有効投与量として設定された。しかし， 


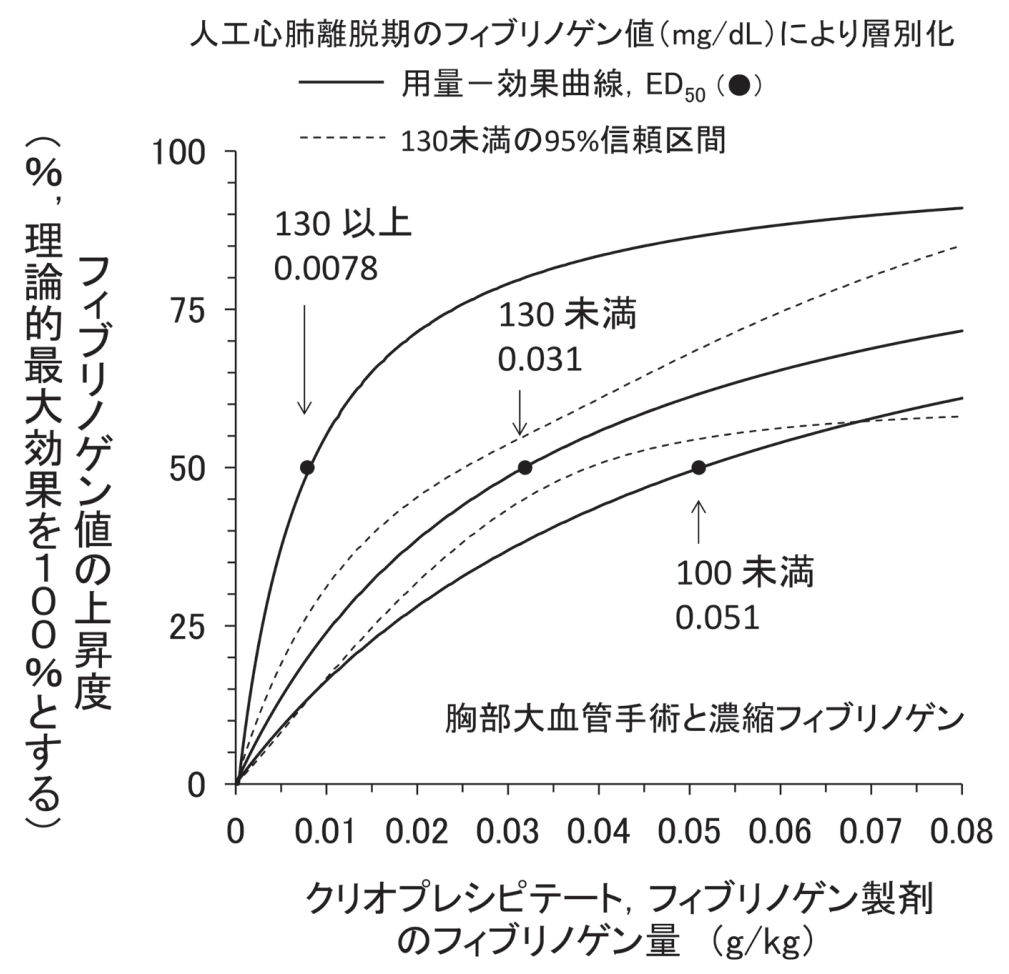

図2 濃縮フィブリノゲンの用量-効果曲線

胸部大血管手術におけるクリオプレシピテート，フィブリノゲン製 剤のフィブリノゲン量 $(\mathrm{g} / \mathrm{kg})$ とフィブリノゲン值の上昇度 $(\%)$ の用 量-効果曲線と $\mathrm{ED}_{50}(\boldsymbol{O})$. 縦軸のフィブリノゲン上昇度(\%)は理論 的最大効果が期待できるつィブリノゲン值と比較した実測值の割合 (\%)である. また， $\mathrm{ED}_{50}$ とは理論的最大効果の $50 \%$ レ゙ルル達する フィブリノゲンの投与量である. 人工心肺離脱期のフィブリノゲン 值 $(\mathrm{mg} / \mathrm{dL})$ が 130 未満(破線：95\%信頼区間)～100未満のとき, 有 効投与量は体重 50 ～70kg あたりフィブリノゲン量として約 $2 \sim 3 \mathrm{~g}$ である.

〔文献3)上り引用・改変〕

出血量や輸血量の転帰に有効性が認められず，有効 投与量であるとは言い難いであろう。筆者らは，フ イブリノゲン量 $(\mathrm{g} / \mathrm{kg})$ とフィブリノゲン值の上昇 度 $(\%)$ の用量 - 効果曲線から有効投与量 $\left(\mathrm{ED}_{50}\right)$ を決 定した ${ }^{3)}$. 図2において, 縦軸のフィブリノゲン上 昇度 $(\%)$ は理論的最大効果が期待できるフィブリノ ゲン值と比較した実測值の割合（\%)である。そして， $\mathrm{ED}_{50}$, すなわち理論的最大効果の $50 \%$ レベルに達 するフィブリノゲン量は人工心肺離脱期にフィブリ ノゲン $100 \mathrm{mg} / \mathrm{dL}$ 未満では $0.05 \mathrm{~g} / \mathrm{kg}, 130 \mathrm{mg} / \mathrm{dL}$ 未 満では $0.03 \mathrm{~g} / \mathrm{kg}$ であった。これは体重50〜 70kg あ
たりフィブリノゲン $2 \sim 3 \mathrm{~g}$ である。この量は, 本邦 のフィブリノゲン製剤の添付文書にある 1 回 $3 \mathrm{~g}$ の用 量とほぼ一致している。ちなみに，人工心肺離脱期 における $130 \mathrm{mg} / \mathrm{dL}$ 以上での有効投与量は $0.0078 \mathrm{~g} /$ $\mathrm{kg}$ であった。これは体重50〜70kg あたり約 $0.4 〜$ $0.5 \mathrm{~g}$ に相当し，FFP 2〜4単位で補充できる。この ように, FFPでも十分に対処しうる症例層を対象 に有効投与量をはるかに上回る濃縮フィブリノゲン の高用量を投与してもその有効性を検出することは 難しい. 

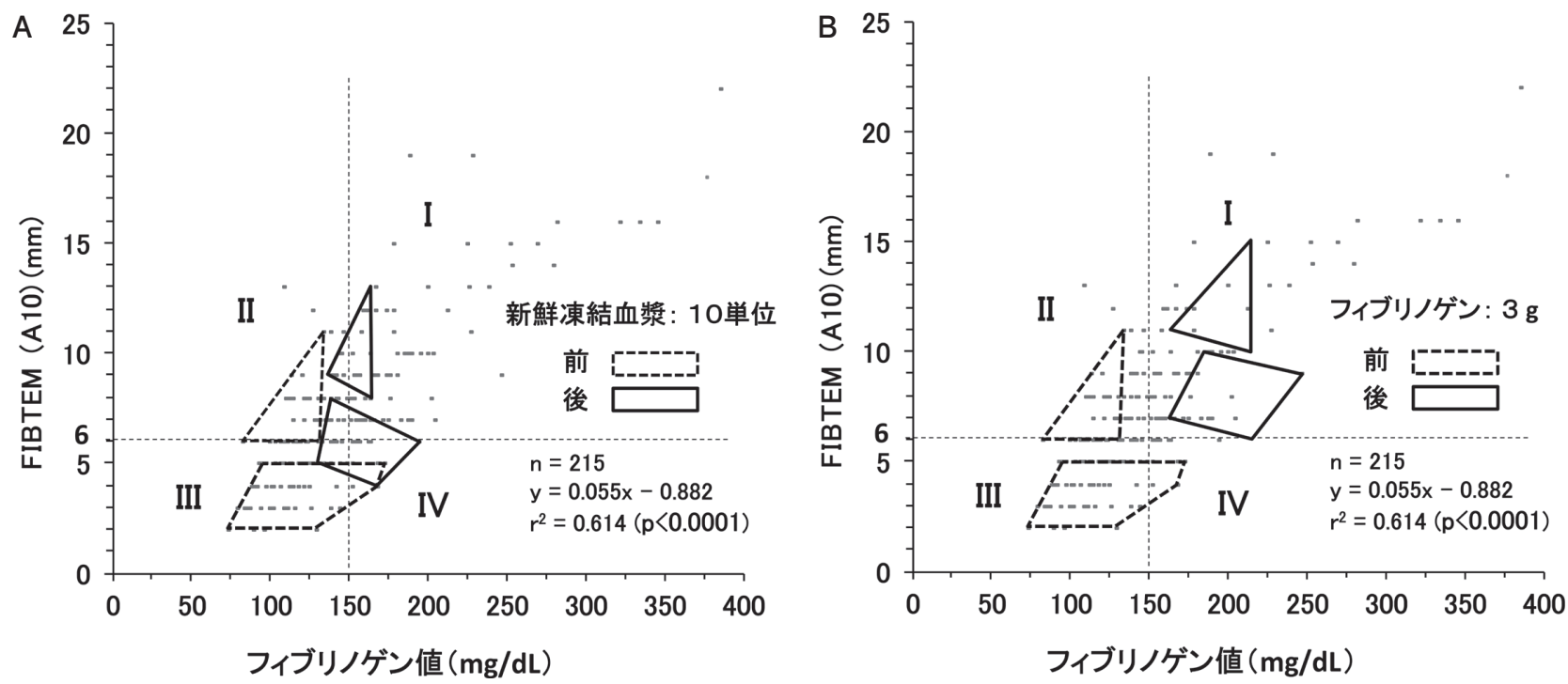

図3 人工心肺復温時の 4 群 (フジサン) 分類

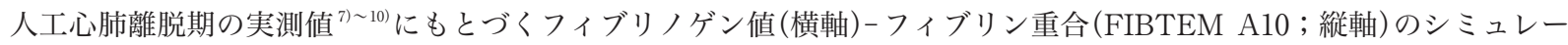
ション。フィブリン重合 $6 \mathrm{~mm}$ 未満では，新鮮凍結血漿 10 単位を投与しても約 6 割が $6 \mathrm{~mm}$ 以上にならない $(\mathrm{A})$. しかし， 濃縮フィブリノゲン $3 \mathrm{~g}$ を投与すると $6 \mathrm{~mm}$ 未満の症例すべてが $6 \mathrm{~mm}$ 以上になる $(\mathrm{B})$.

〔文献 7)～10)より引用・改変〕

\section{III トリガ一值と有効投与量の検証}

ここで，トリガー值 $130 \mathrm{mg} / \mathrm{dL}$ の設定とフィブリ ノゲン $3 \mathrm{~g}$ の有効性についてシミュレーションを用 いて検証してみよう。

筆者らはフィブリノゲン $130 \mathrm{mg} / \mathrm{dL}$ 未満をトリガ 一値として設定した。これは，人工心肺離脱期にト ロンボエラストメトリーにより測定されるフィブリ ン重合(FIBTEM A10)が6mm未満となるカットオ フ值である。そのフィブリン重合が $6 \mathrm{~mm}$ 未満にな ると術後出血量と輸血量は有意に増加する ${ }^{7}$. 当然 ながら，フィブリノゲンの濃度よりもフィブリンの 重合能のほうが凝固した血餅の強さ，すなわち術野 の止血能を良く反映する。そこで，濃縮つィブリノ ゲンの効果を理解しやすいように，フィブリノゲン 值(横軸)とフィブリン重合(縦軸 FIBTEM A10)の シミュレーションモデルを見てみよう ${ }^{8) ~ 10) . ~ こ れ ら ~}$ のシミュレーションは人工心肺離脱中の実測值にも とづいている7)。図3Aのように, FIBTEM A10が
$6 \mathrm{~mm}$ 未満の症例では FFPを 10 単位投与しても，そ の約 6 割が止血能の脆弱な $6 \mathrm{~mm}$ 未満に留まる。一 方，図3Bのように，フィブリノゲン $3 \mathrm{~g}$ を投与する と $6 \mathrm{~mm}$ 未満の症例すべてが $6 \mathrm{~mm}$ 以上になり，正 常な止血能を回復しうる。つまり，濃縮つィブリノ ゲンの出血量や輸血量を減らす効果は，人工心肺離 脱時に $6 \mathrm{~mm}$ 未満の症例においてより明確になる. しかし，前述のように止血能が良い $6 \mathrm{~mm}$ 以上では FFPで十分対処でき濃縮フィブリノゲンの効果は 乏しいと考えられる。

\section{IV＼cjkstart統計処理の工夫について}

周術期の出血量や輸血量を転帰とする研究では, 患者背景，手術や人工心肺の時間，その他多くの要 因によってデータがばらつきやすい。群間の有意差 が得られにくく大規模な症例数が必要になるので, 統計処理に工夫が必要である.

前述の筆者らの観察調査においても出血量は人工 心肺離脱期のフィブリノゲン值に左右されて大きく 

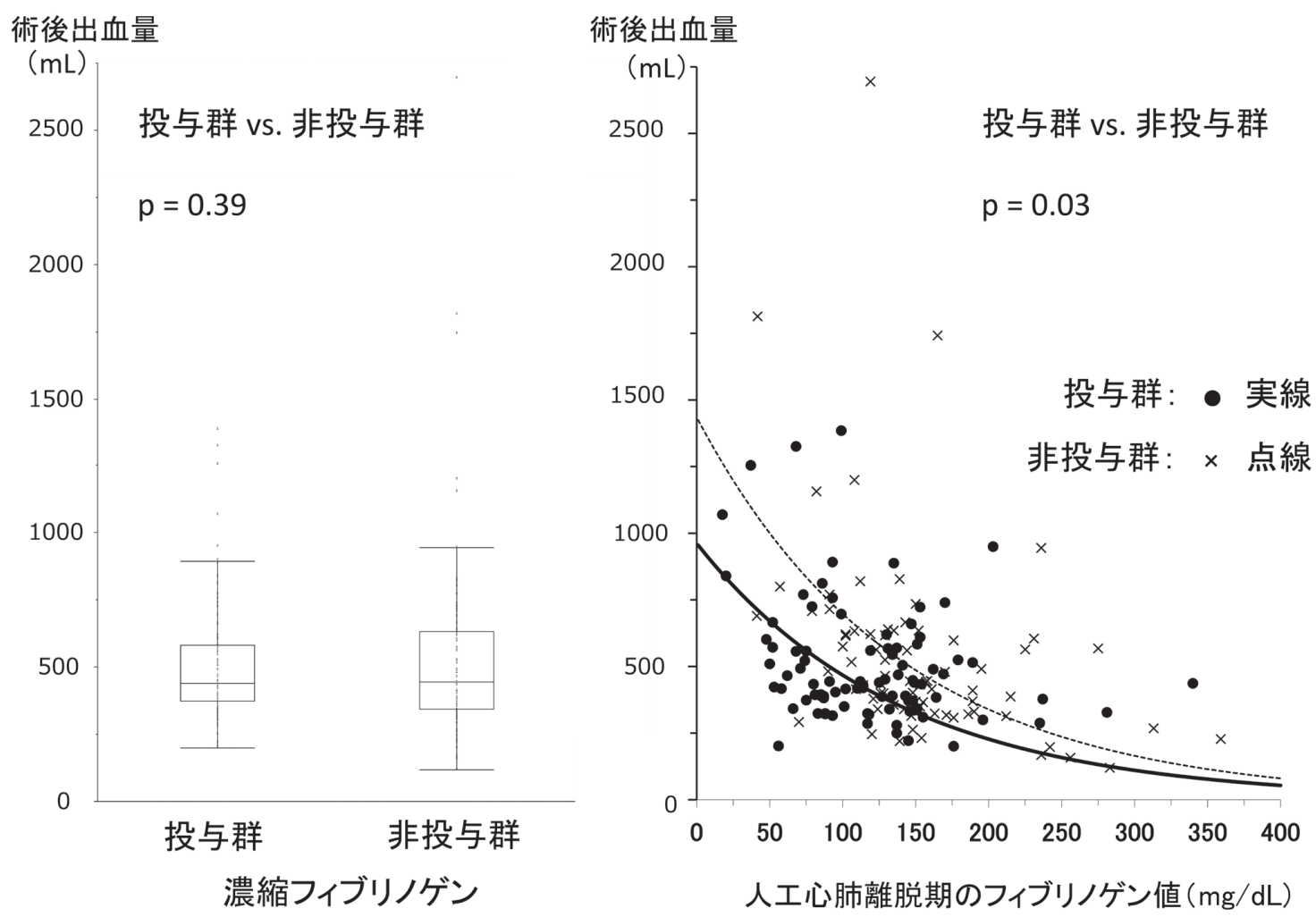

図4＼cjkstart濃縮フィブリノゲンの術後出血量に対する有効性の解析方法

術後出血量について濃縮フィブリノゲンの投与群と非投与群の間に有意差がないが(左図), フィブリノゲ ン值(横軸)に対して術後出血量(縦軸)を共変量として, 一般化線形モデルで非線形回帰を行いながら多変 量解析すると, 投与群のほうが非投与群よりも有意に出血量が少ない.

〔文献3)上り引用・改変〕

ばらついている ${ }^{3)}$. 図4(左)のように, 濃縮フィブ リノゲンの投与群と非投与群のばらつきを表す四分 位範囲は大きく, Student-t検定では 2 群間に有意 差がない。サンプルサイズ計算から有意差が得られ る症例数は約 $500 \sim 1,500$ と推定され, 大規模な多施 設研究でもしないかぎり不可能である。そこで, 出 血量を左右するフィブリノゲン值の影響を加味して 2 群を比較する方法を選択した。実際には, 図4(右) のように，フィブリノゲン值 (横軸)に対し術後出血 量(縦軸)を共変量として非線形的に相関させる。こ のように比較すると 2 群間に有意な差が得られた。 ここでは，出血量とフィブリノゲン值が直線よりも 曲線的に回帰するので，一般化線形モデルを用いた 非線形回帰分析を行っている。 また，横軸のフィブ リノゲン值が低下していくと出血量の差が大きくな
るので層別化すると両群の差が明確になりやすい. さらに, 術前検査, 体重, 人工心肺時間などの因子 を含めた多変量解析を行うこともできる。

\section{$\mathrm{V} \quad$ 新しい観察調査と臨床試験への期待}

胸部大血管手術の人工心肺離脱期に，フイブリノ ゲン值が $130 \mathrm{mg} / \mathrm{dL}$ 未満の症例においては濃縮フィ ブリノゲンが止血と輸血節減に役立つであろう。し かし, 欧米のような二重盲検法の無作為比較試験を $130 \mathrm{mg} / \mathrm{dL}$ の症例を対象に行うのは安全面から難し い. 臨床試験に参加できるような施設ではすでに保 険適応外のフィブリノゲン製剤が使用されていた り,クリオプレシピテートが院内供給されていたり する。よって, 人工心肺離脱期にプラセボ群だから といって濃縮フィブリノゲンを投与しないリスクは 


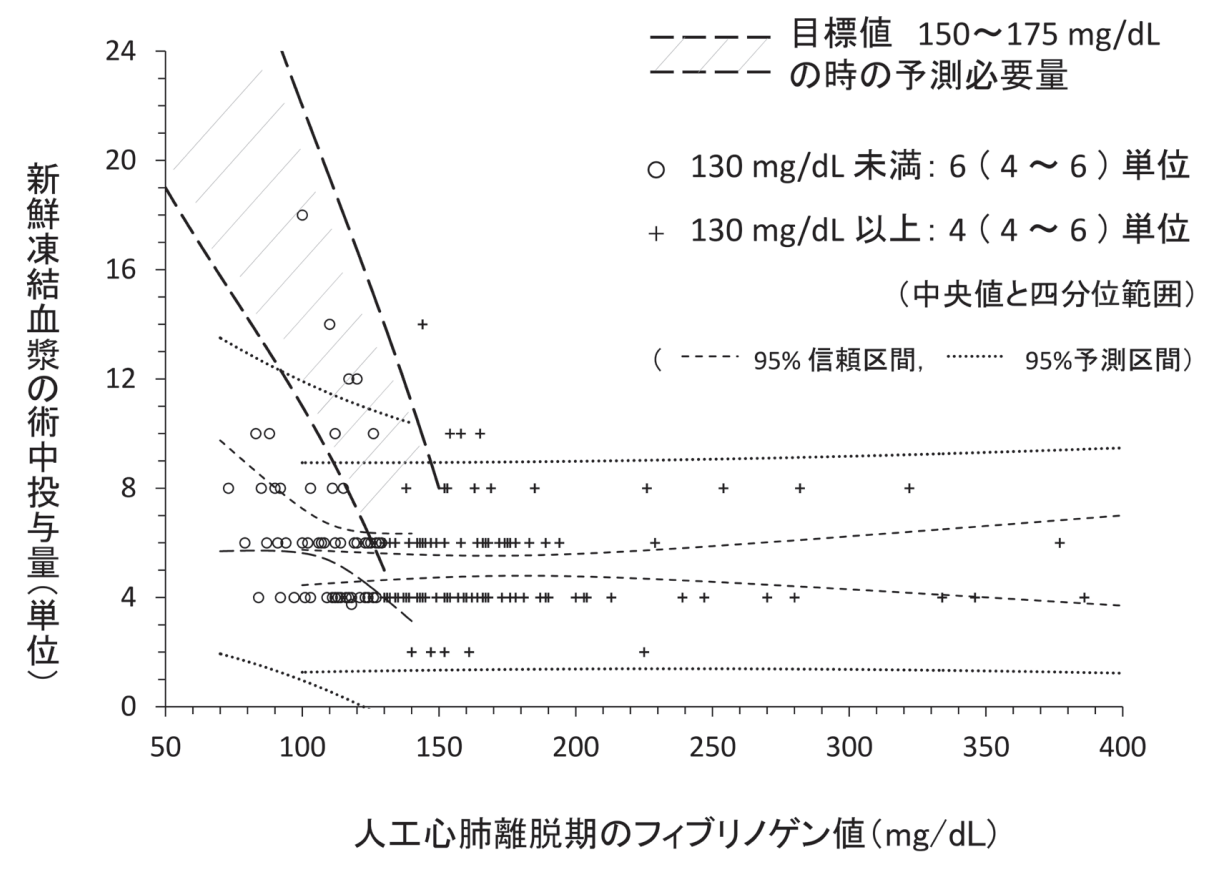

図 5 開心術における新鮮凍結血漿の術中投与量(非投与例は除外)

開心術において人工心肺離脱期のフィブリノゲン值 $(\mathrm{mg} / \mathrm{dL})$ と術中に投与された 新鮮凍結血漿(単位)との関係をフィブリノゲン值 130 未満と 130 以上の症例層に区 分して示した (文献 7 の再解析より)。散布図と $95 \%$ 信頼区間および $95 \%$ 予測区間 を図のように破線で示し, 各症例層で投与さ机た新鮮凍結血漿の中央值と四分位範

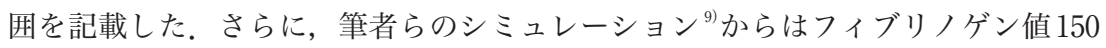
$\sim 175 \mathrm{mg} / \mathrm{dL}$ を目標にすると実際の新鮮凍結血漿の使用量(130未満： $\bigcirc, 130$ 以上： +)よりも投与過剩になりやすいことが示唆された.

〔文献7), 9)上り引用・改変〕

かなり高い。予想されるリスクが安全性を大きく上 回る場合には，無作為比較試験の実施には限界があ ると考えられる。一方，同一施設や多施設において 濃縮フィブリノゲンの導入後の出血量や輸血量の減 少傾向を分析することもできる。このような観察調 査はより安全な疫学的方法であろう。多施設で観察 調査を行うことができれば施設間の違いを超えて濃 縮フィブリノゲンの有効性と適用を探索できるかも しれない.

一方, 開心術の人工心肺離脱期ではやや話が異な る。フィブリノゲンが $130 \mathrm{mg} / \mathrm{dL}$ 未満の症例におい て濃縮フィブリノゲンの有効性を無作為比較試験で 検証することはより安全かもしれない。われわれが 以前に開心術で行った研究では, 人工心肺離脱期に
フィブリノゲンが $130 \mathrm{mg} / \mathrm{dL}$ 未満の症例に投与され た FFP は中央值で 6 単位(四分位範囲 : 4〜6)であっ た(図5)。FFPのフィブリノゲン量を200〜250mg/ $\mathrm{dL}$ とすると，6単位は濃縮フィブリノゲン $1 \sim 2 \mathrm{~g}$ に相当する．FFPは容量負荷による肺水腫や輸血 関連肺障害の危険性もあるので，濃縮フィブリノゲ ンは容量負荷が少なく，効率の良い止血と輸血節減 の効果が期待できるかもしれない。ささらに，図5の ように，筆者らのシミュレーション ${ }^{9)}$ 用いてフィ ブリノゲン $150 〜 175 \mathrm{mg} / \mathrm{dL}$ 目標にしたときの FFPの投与量を推測した。すると，実際の投与量 を大きく上回り，開心術においても目標値を設定し て投与すると輸血過剩になりやすいと考えられた。

濃縮フィブリノゲンの明確な適用と投与基準を設 
けている施設はまだ少ない。安全性, 善意の献血に もとづく血液資源の有効活用，血液製剂の適正使用 という観点から, 新しい観察調査と臨床試験への期 待は今後高まっていくかもしれない.

利益相反はなし。

\section{参考文献}

1) Rahe-Meyer N, Levy JH, Mazer CD, et al. : Randomized evaluation of fibrinogen vs placebo in complex cardiovascular surgery (REPLACE) : a double-blind phase III study of haemostatic therapy. Br J Anaesth $117: 41-51,2016$

2) Bilecen S, de Groot JA, Kalkman CJ, et al. : Effect of Fibrinogen Concentrate on Intraoperative Blood Loss Among Patients With Intraoperative Bleeding During High-Risk Cardiac Surgery : A Randomized Clinical Trial. JAMA $317:$ 738-747, 2017

3）木倉晆人, 當別當庸子, 上原博和ほか：胸部大血管手 術に抢けるフィブリノゲン補充療法の有効性と適用一 後方視的コホート研究一. 麻酔 $66: 376-382,2017$

4）富田有毅彦, 下出典子, 井手岳ほか：胸部大動脈人工 血管置換術症例における体外循環離脱後の凝固障害に
対するクリオプレシピテートの有用性の検討．麻酔 $60: 830-834,2011$

5）厚生労働省医薬・生活衛生局：「血液製剂の使用指針」(平 成 29 年 3 月改定版). 〈http://www.mhlw.go.jp/file/06Seisakujouhou-11120000-Iyakushokuhinkyoku/ 0000161115.pdf〉(最終アクセス；2017年 10 月 21 日)

6) Levy JH, Welsby I, Goodnough LT : Fibrinogen as a therapeutic target for bleeding : a review of critical levels and replacement therapy. Transfusion 54 : 1389-1405, 2014

7) Kawashima S, Suzuki Y, Sato T, et al. : Four-Group Classification Based on Fibrinogen Level and Fibrin Polymerization Associated With Postoperative Bleeding in Cardiac Surgery. Clin Appl Thromb Hemost $22: 648-655,2016$

8）木倉睦人, 川島信吾, 鈴木祐二ほか：大量出血と止血 凝固検查一フィブリノゲン補充療法とトロンボエラス トメトリー $\left(\mathrm{ROTEM}^{\circledR}\right)$ の重要性とその意義一。日本臨 床麻醉学会誌 $34: 539-548,2014$

9）浜松労災病院麻酔科ホームページ。〈http://www. hamamatsuh.johas.go.jp/raiin/bumon/31masuika/ 31masuika.html $>$ (最終アクセス；2017年 10月 21 日)

10）鈴木祐二, 川島信吾, 佐藤恒久ほか：フィブリノゲン 值とフィブリン重合の複合シミュレーションと自験症 例によるフィブリノゲン補充療法の評価. 麻酔 65 ： 566-572, 2016 


\title{
The Reason Fibrinogen Concentrate Failed to Show Efficacy in Clinical Trials in Western Countries
}

\author{
Mutsuhito KIKURA \\ Department of Anesthesiology, Hamamatsu Rosai Hospital
}

Randomized double-blind trials in western countries have failed to demonstrate the efficacy of fibrinogen concentrate (3-6 g) for perioperative hemostasis or demonstrate a reduction in blood transfusion in patients undergoing complicated cardiovascular surgery. The main reason for these negative findings in clinical trials is that the mean fibrinogen level of $170-180 \mathrm{mg} / \mathrm{dL}$ at the end of cardiopulmonary bypass is too high to induce the efficacy of fibrinogen concentrate and fresh frozen plasma is sufficiently effective for hemostasis in an area with a high level of fibrinogen. In our previous study, we demonstrated that the actual trigger level for fibrinogen concentrate was $<130 \mathrm{mg} / \mathrm{dL}$ in thoracic aortic surgery, and the effective dose of fibrinogen was approximately 2-3 g per 50-70 kg in body weight. In the future, a new and safe approach that is based on objective study and clinical trials is sure to elucidate the trigger level and the effective dose of concentrated fibrinogen for patients undergoing cardiovascular surgery.

Key Words : Randomized clinical trial, Fibrinogen, Trigger level, Effective dose, Cardiovascular surgery

The Journal of Japan Society for Clinical Anesthesia Vol.38 No.2, 2018 